\title{
MAHDUMKULU'YU ANLAMAK: A. ZEKİ VELIDİ TOGAN ÖRNEĞİ
}

\author{
"Mahtumkulu tercüme hali hakkında bar taba [tapıp] \\ aldığımız malumat uşbudur [budur]. \\ Türkmenler arasında bu hakta malumat \\ alıp yazan kişi bolsa elbette edebiyat \\ tarihımızga zor hıdmet itken bolur idi”
}

\section{$\ddot{O} z$}

Tasavvuf meşrepli Türkmen şairi ve düşünürü Mahtumkulu’yu anlamak ve anlatmak, tarihî süreç içinde değişik zamanlarda ayrı ayrı ilim adamları tarafından istenmiştir. Bu bilimsel edim genel olarak iki yönden ele alınabilir. Bunların birincisi sufi şairin şiirlerinin yazmalarının doğru okunup belirlenmesi, diğeri ise anlamlarının bilinmesidir. Bunlar gerçekten de sorgulanması gereken konulardır. Kısacası birincisi anlamlar ya da kavramları oluşturucu kültürel birikimlerin yansıması olan yapıtın veya şiirin yayımlanmasıyla, diğeri ise şairin kelimelere yüklediği anlam ilgilidir. Şaire ait şiirlerin incelenerek yayımlanması şiir külliyatını anlamanın bir yönünü oluşturuyorsa, o günün sosyal - düşünce yapısının bilmek ise diğer tamamlayıcı tarafını oluşturduğu söylenebilir. Bu konu doğru yapıldığında veya anlamlandırıldığında XVIII. yüzyılın Türkmen bilinç ve düşünce yapısını belirlenmesinde olumlu etkisi olacaktır. $\mathrm{Bu}$ demektir ki, aklı önemseyen irfan ehlinden olan Türkmenlerin XVIII. yüzyıldaki bilinç ve düşünce yapısını bilmekle olumlu yaklaşım olabilir. Şairin şiirlerinin yayımlanması ve anlamlandırılması veya içeriği konusunda yol gösterici olan, diğer bir ifade ile bunu gerçekleştirmeye canı gönülden çalışan Ahmet Zeki Velidi Togan'ın yazılarını irdeleyerek belirlemeye çalışacağız. Togan'ın kültürel ortam ve olanakları kullanarak kendisinden önce ve zamanesindeki Mahtumkulu'nun şiirlerinin neşri ve şair hakkındaki betimlemeleri eleştirel değerlendirmelerine geniş yer verilecektir ve başvurulacaktır. Bununla beraber Togan Mahtumkulu'nun şiirlerini kapsamlı olarak ilk defa Orenburg'da 1913 senesinde Şura mecmuasının 12.-17. sayılarında yayımlanması ve şairi "Mahtumkulu'nun şiirleri dinî olmakla beraber "meşrep" veya "Ahmed Yesevi" gibi halis tasavvuf eseri ve derviş şiirleri değil diye tanımlamasıdır. Bu bir halk din ve ahlak muallimi, halk felsefiyati muallimidir" diyerek koşulsuz nitelendirmesi açıklanmaya ve çözümlenmeye çalışılacaktır.

Anahtar Sözcükler: Mahtumkulu, Türkmen edebiyat1, Zeki Velidi Togan, şiir.

\footnotetext{
*Yrd. Doç. Dr.; Bülent Ecevit Üniversitesi, İlahiyat Fak. Din Bilimleri Ana Bilim Dal1, tahirashirov@gmail.com.
} 


\title{
UNDERSTANDING MAKHTUMGULI: A. ZEKİ VELIDİ TOGAN
} EXAMPLE

\begin{abstract}
Understanding and explaining the Turkmen poet and thinker Makhtumguli whose ideas are of customs of Sufism have been tried by various scientists at different times throughout history. Thus this scientific practice can be examined in two ways. The first is reading the Sufi poet's poetry in the right way and the other is understanding their meanings. They are indeed an issue that should be questioned. In short, the first point is related to the process of understanding the cultural heritage composing the concepts of meaning and terminology which is the reflection of the poetic construction and its publication and the second one is related to the meanings which the poet himself loaded to the words respectively. If half of the process of understanding the poet's corpus poetry constitutes publishing his poetry after examined carefully, being aware of the socio-mental structure of his contemporary time should constitute the other complementary half. If this issue carried out accurately, it will impact positively on determining the consciousness and thinking of Turkmens in XVIII century. This means by knowing the mental thinking system of XVIII century Turkmens - the people of the wisdom - who has high opinions about intelligence, an appropriate approach will be displayed. We will try to examine and study the works of Ahmet Zeki Togan which is a guide in publishing, entailing meaning and in other content related issues of Makhtumguli's poems, in another words who has put his heart and soul in his work. An ample space will be given to Togan's critical evaluations of the publications of the poems and portrayal of Makhtumguli in Togan's own contemporary time and before. And they will be referred to. In the mean time, it will be clarified and analysed that the fact that Togan firstly published Makhtumguli's poems comprehensively in 12-17 issues of the magazine called "Shoora" in Orenburg in 1913 and his unconditional characterisation of the poet as "Being religious Makhtumguli's poems are not "meshrep" (spiritual) or pure "tasavvouf" (sufism) and dervish poems like the poems of Ahmet Yesevi. He is a religious and moral educator of people - a philosopher of the public."
\end{abstract}

Keywords: Mahtumkulu, Turkmen literature, Zeki Velidi Togan, poetry.

\section{Giriş}

Tasavvuf meşrepli Türkmen şairi ve düşünürü Mahtumkulu'yu anlamak ve anlatmak, tarihî süreç içinde değiş̧ik zamanlarda ayrı ayrı ilim adamları tarafından istenmiştir. Bu bilimsel edim genel olarak iki yönden ele alınabilir. Bunların birincisi sufi şairin şiirlerinin yazmalarının doğru okunup belirlenmesi, diğeri ise anlamların bilinmesidir. Bunlar gerçekten de sorgulanması gereken konulardır. Kısacası birincisi anlamlar ya da kavramları oluşturucu kültürel birikimlerin yansıması olan yapıtın veya şiirin yayımlanmasıyla ilgili diğeri ise şairin kelimelere yüklediği anlamladır. Şaire ait şiirleri incelenerek yayımlamak şiir külliyatı anlamanın bir yönünü oluşturuyorsa, o günün sosyal - düşünce yapısını bilmek ise diğer tamamlayıcı tarafı olduğu söylenebilir. $\mathrm{Bu}$ konu doğru gerçekleştirildiğinde veya anlamlandırıldığında XVIII. yüzyılın Türkmen bilinç ve düşünce yapısının belirlenmesinde olumlu etkisi olacaktır. Bu demektir ki, aklı önemseyen irfan ehlinden olan Türkmenlerin XVIII. yüzyıldaki bilinç ve düşünce yapısını bilmekle olumlu yaklaşım sergileneceğidir. Bu 
yazıda, şairin şiirlerini yayımlanması ve anlamlandırılması veya içeriği konusunda yol gösterici olan, diğer bir ifade ile bunu gerçekleştirmeye canı gönülden çalışan Ahmet Zeki Velidi Togan'ın yazılarını irdeleyerek belirlemeye çalışacağız. 1890 - 1970 yıllara arasında yaşan düşünür Zeki Velidi Togan'ın kültürel ortam ve olanakları kullanarak kendisinden önce ve dönemindeki Mahtumkulu'nun şiirlerinin neşri ve şair hakkındaki betimlemeleri eleştirel değerlendirmelerine geniş yer verilerek irdelenecektir.

Ord. Prof. Dr. Zeki Velidi Togan'ın kendisi hayatını ve mücadelesini anlattığ1 "Hatıralar" adlı eserinde "Bu hatıralara kaynak olan malzeme bizim 1923 başında Türkmenistan'dan İran'a geçmemizden önce Buhara'nın Kabil Elçiliği ve Muhammedabat'a giden tüccarlar vasıtasıyla dışarıya çıkarılmıştı..." diyerek ön sözle başlamaktadır (Togan, 1999). Bu hatıralar kısaca Zeki Velidi Togan'ın hayatı ve Türkmenler ile ilgili görüşlerine ve bilgilerine delil olarak ifade edilebilir. Nitekim kendi ifadesiyle "Aşkabat'ta geçirdiğimiz günler” başlığı altındaki "Berdi Hacı'nın oğlu eski dostum avukat Kakacan ile "Türkmenistan” gazetesini çıkardık” iddiası, Köne - Ürgenç ahvali, kum içinde bir Türkmen çadırında misafirlik durumu ve diğerlerini ilgili görüşleri ış1k tutabilmesi bakımından başvurulacak kaynaktır (Togan, 1999: 285, 300, 307).

Bununla beraber "Mahtumkulu hakikaten muallim şair olmakla beraber halk müfekkiri" diye ifade eden Zeki Velidi Togan'ın Mahtumklu'nun şiirlerini kapsamlı olarak ilk Orenburg'da 1913 senesinde Şura mecmuasının 12.-17. sayılarında yayımlanması ve Türkiyat mecmuasının "Kitabiyat tenkid ve tahlilleri” bölümündeki Şeyh Muhsin Fani tarafindan şerh ve tenkitli "Mahtumkulu divanı ve yedi asırlık Türkçe bir manzume" adlı kitaba (Aşyrow, 2014) yazılan geniş analizlerinde şairi koşulsuz nitelendirmesi esasında açıklanmaya ve çözümlemeye çalış1lacaktır.

\section{Mahtumkulu'nun hakkında kaynaklar ve o kaynaklarda şair}

Zeki Velidi Togan'ın Türkmen Şairi Mahtumkulu ve onun şiirleri ile ilgisi çok erken zamanlardan başladığını söyleyebiliriz. Ancak düşünürün, Astrahanlı İmam Abdurrahman Efendi Niyazi’nin 1912 senesi “Mahtumkulu Divanı"nı neşir etmesiyle (Divan Mahtumkulu, 1912) şairin hayatı ve şiirleri üzerinde daha derin bir çalışma başlattı̆̆ı bir yönü ile söylenebilir. Gerçekten de düşünürün Mahtumkulu ve şiirleri hakkında yazmasının bir sebebinin de Astrahan'da yaşayan Türkmen âlimi Abdurrahman Niyazi'nin neşrinde Mahtumkulu'nun şiirlerinin çok sınırlı olması söylenebilir. Ayrıca düşünürün Türkmen şairi Mahtumkulu'nun şiirlerinin Abdurrahman Niyazi tarafından neşrini övgü ile bahsetmekle birlikte Türkmen edebiyatı konusunda büyük hizmet olduğunu da vurgulamıştır (Şura, 1913: 12 / 357). 
Düşünür, Türkmen dil biliminin ve edebiyatının öğrenilmesiyle Mahtumkulu’yu daha doğru anlama olanağına sahip olunacağını görüşüyle bazı Türkî halkların dilleri ile ilgilenen müsteşriklerin isimlerini sıralamıştır ${ }^{1}$ ve onların teftiş etmediklerini belirtmiştir ${ }^{2}$. Ayrıca İ. N. Berezin'in "Турецикая хрестоматія" adlı 1857 - 1876 yıllar arasında neşredilen eserinin 3. cildinin 40 - 102 sayfaları arasında Türkmen halkının edebiyatı ile ilgili bilgilerin olduğunu anlatmaktadır (Şura, 1913: 12 / 358).

Ayrıca Vambery tarafindan 1870 yılında Leipzig'de "Zeitschrift der Deutschen Morgenländischen Gesellschaft”3 dergisinin 33. cildinde yayımladığını belirtmektedir. Bununla bağlantılı olarak şair Mahtumkulu'nun adının nasıl yazılacağı konusunda dipnotta değerlendirme yapmaktadır. Nitekim Vambery'nin, Bakulin'in, Abdurrahman Niyazi Efendi'nin "Mahdumkulu” şeklinde yazmalarına rağmen bazı yazmalarda ve Samoyloviç tarafından "Mahtumkulu" şeklinde yazıldığını belirttikten sonra kendi elindeki yazmada "Mahtumkulu” şeklinde yazıldığından kendi yazmasına sadık kaldığını ifade etmektedir.

$\mathrm{Bu}$ mevzunun Türkmen edebiyatında önemli tartışma konularından biri olduğu görülmektedir. Ayrıca bu konuda Aşkabat'ta 1904 yılında Rus dilinde neşir edilen S. Agabekov'un “Türkmen Hazar Ötesi Bölgesinin Atasözleri ve Deyimleriyle Türkmen Dili Ders Kitabı" adlı kitabına gönderme yapmaktadır (Agabekov, 1904). Ancak Türkmen dili ve edebiyatı hakkında meşhur müsteşrik A. N. Samoyloviç’e kadar önemli bir yol kat edilmediğini zikir etmektedir ve oryantalistin kaleme aldığı yazıları sıralamaktadır ${ }^{4}$. Ayrıca Samoyloviç ile tanışmasına da şair Mahtumkulu'nun sebep olduğunu şu sözler ile anlatmaktadır: "Dostluğumuz 1913 senesinde Türkmen şairi Mahdumkulu'ya ait neşrettiğim bir makale dolayısıyla başlamıştı. $\mathrm{Bu}$ zat, 1921 senesinde Buhara'ya benimle görüşmek için gelmişti” (Zeki Velidi Togan, Hatıralar, s. 525). Yazar sonra ise O. Bakulin'in şair Mahtumkulu ile ilgili yazısına atıfta

\footnotetext{
1 “Rodlov, Katanov, Kons, Milioranskiy, Vambery, İlminskiy” Şura, 12/357.

2 Şura, 12/358; Записок Восточного Отд. Имп. Русс. Археолог Общества. За. 1909, т. XIX, 151.

${ }^{3}$ Vambery, H., "Die Sprache der Turkomanen und der Diwan Machdumkuli's". ZDMG (Zeitschrift der Deutschen Morgenländischen Gesellschaft), XXXIII, s. 387-444.] [İngiliz hükümetinin görevlendirmesiyle Arminius Vamberi 1863 'de Orta Asya'ya, bu cümleden olarak Türkmenistan'a da derviş kılığında seyahat eder. O Mahtumkulu'nun 40 şiirini toplayıp, 1879'da Laipsig şehrinde, 31 şiiri Türkmence ve Almanca tam metin olarak, 9 şiirden parçaları ise "Türkmen dili ve Mahtumkulu divanı" adlı bir kitapçık olarak yayınlar.

${ }^{4}$ Zeki Velidi Togan'ın Şura dergisinde Aleksandr Nikolayeviç Samoyloviç'in (1880-1938) yazıları : “1) 1906-7 yıllardaki seyahatleri hakkında Зап. В. О. И. Р. А. Общ. XVIII c. hem Извътія Русскаго Комитета для изученія Средней и восточной Азіи № 9.'da çıkgan otçotları, 1902-nci yılga seyahati hakkında Отчеты осостояніи и дъятельности И. С. П. Б. Университета, Записки о наградахъ' in 1902 y1lga cildinde hem 1903-nci y1lga 73-74-nci sahifelerinde yazılgan kıska atçotları. 2) Туркменсій (turkmenskiy olmalı) поэть Керчмолла ismi ile Живая Старина jurnalının 1907-nci yıl 4-nci cüz'inde neşir etgen makalesi. 3) 1909-nci yıl 3. В. О. И. Р. А. О. mecmu'esinin 19-nci cültinde, 51-530 sahifelerde "Orta Aziya/Asya edebiyatına ait erbir (materiallar)" diyip yazgan kiymetli makalesi. 4) Şuluk mecmu'enin şuluk cildinde, s. 5125-5148'de Указателъ къ пъснямъ Махтумъ Кули diyip yazgan makalesi. 5) Живая Старина 1909-nci yılga II-III-nci cüz'inde s. 52-79 "Kaspi Orta Türkmenlerin tabışmakları" diyip yazganı. Onun uşbu isimdeki on makalesi "Türkistaniskiy vidomodtiy"de basıldı. 1902-nci yıl numer 141." Şura, 12/358.
} 
bulunmakla ${ }^{5}$ Almanca yazılarında olduğunu belirtmiştir. Ancak kendisinin Almancaya aşinalığının olmadığından bahseder ${ }^{6}$.

Zeki Velidi Togan Türkmen edebiyatı konusunda Samoyloviç ile Bakulin eserlerinden istifade etmenin mümkün olduğunu belirttikten sonra Samoyloviç'in "Orta Asya edebiyatına ait materyaller" adlı yazısına başvurmakta ve değerlendirmesine yer vermektedir (Şura, 1913: 12 / 358 - 359). Orta Asya şairlerinin şiirlerinin kendine özgü niteliklerinin olduğunu ifade etmektedir. Gerçekten de Ali Şir Nevai grubu şairleri Arap vezni, Ahmet Yesevi gibi İran med üzere olmakla 7 ve 11 mısralı bina edildiğini söylemektedir ve örneklemektedir. Ancak Orta Asya halk şairlerinin dört mısralı şiirleri severek yazdıklarını ifade etmektedir (Şura, 1913: 12 / 359).

F. Bakulin'in "Pesni Turkmen i poet ih Mahdum-Kulu" (Türkmen şarkıları ve onların şairi Mahtumkulu) adlı yazısına gönderme yapmaktadır (Bakulin, 1872). Şarkıcıların genellikle onların şarkılarından söylediklerine yer vermiştir (Şura, 1913: 12/359). Bölümün sonunda Samoyloviç’in 36 kadar halk şairinden bahsettiğini ifade etmektedir ve ilk olarak Mahtumkulu'yu zikir etmektedir ${ }^{7}$. Halk şairi Mahtumkulu'nun hayatı hakkında söz açarak konuya girmektedir.

Zeki Velidi Togan Şura dergisinin 13. sayısındaki "Divani Mahtumkulu" adlı seri yazısının "Mahtumkulu ve Onun Eş'ari” adlı bölümünde şairin Türkmen halkının gönül sultanı olduğuna Bakulin'in yazısını aktararak başlamaktadır (Şura, 1913: 13/393). Ayrıca şairin ölüm tarihi hakkında ise Vambery'nin verdiği bilgiye başvurmakla bir değerlendirmeye gitmiştir. Düşünür Kızıl Ahund olarak bilinen Türkmen mollasının verdiği bilgiye göre, Vambery’nin Orta Asya seyahatinden (1863) on sekiz yıl sonra vefat ettiği sonucu çıkarmaktadır (Şura, 1913: 13 / 393). Zeki Velidi verdiği bilgiye göre, şairin 1845 yılında vefat etmiş olduğuna kanaat getirmiştir. Ancak düşünürün tavsiye ettiği kaynağın 80 yıllık olduğunu görebiliyoruz ${ }^{8}$. Vambery'nin Rusça tercümesindeki getirilen cümlede 80 yıl önce vefat ettiği hakkında sözler

\footnotetext{
5 “О. Бакулинъ' in 1872-nci y1l - Извътія Кавказскаго Отдел. Имп. Русс. Геогр. общества mecmu'esinin 1-nci cildinde s. 105-109'de “Türkmen cerleri hem oların şairi Mahtumkuli” diğen makalesi malum”. Şura, 12/358.

${ }^{6}$ Alman alimi Haretman'ın yazılarının olduğunu söyler: Şura, 12/358.

7 "Samoyloviç 36 kadar şairlerini zikir ete. Olar muna uşbulardır. 1) Mahtumkuli, 2) Talibi, 3) Zelili, 4) Marufi, 5) Miskin Kılıç, 6) Molla Nefis, 7) Kör Molla, 8) Allah Berdi - Hara Bek, 9) Ak Molla, 10) Muhtaci, 11) Bende Murat, 12) Zenubi, 13) Kemine) 14) Ata Can, 15) Atabay), 16) Turdı Şair, 17) Devan Şair, 18) Kar Oğlan, 19) Hacili Molla, 20) Ezber, 21) Nuri Şair, 22) İl Geldi, 23) Ahsen Şeyh Yake Dana Ata, 24) Oraz Mengli, 25) Gul Yusuf, 26) Miskin Ali, 27) Karaçi Oğlan, 28) Baş Şair, 29) Sakar Molla, 30) Bay Muhammed, 31) Şeydayi, 32) Bay Muhammed, 33) Şah Bende, 34) Saltık, 35) Cuma şair, 36) Devlet Muhammed.” Şura, 12/360.

8 “Они радуются присутствию бахши (трубадура ), который под аккомпанентам своего дутара, двухструнного инструмента, поет отрывки из Кер-оглы и песни Аман- молы или Махтумкули, национального поэта, почти обожествляемого туркменами. Этот считающий святым был из племени геклен и умер приблизительно 80 лет назад.” Арминий Вамбери «Путешествие по Средней Азии» М. Восточная литература. 2003.
} 
şairin 1783 yılına denk geldiğine ve realiteye yakın olduğuna kanaat getirilir. Ancak düşünürün 1845 yılı çıkarmasına sebep olan belgeyi anlamlandırmak gerçekten zor.

Yine düşünür Samoyloviç’e başvurmakla ${ }^{9}$ Mahtumkulu'nun babası Devletmemmet Molla lakabı "Azadı" adlı şairin olduğunu belirtmektedir. Onun XVIII. yüzyılda yaşadığını ve ahlak ilmine ait "Vagz-ı Azadı - mesnevi" adlı eserinin olduğunu aktarmaktadır (Şura, 1913: 13/39). Sonra düşünür “Mahtumkulu'nun tercüme-i hali hakkında bar taba [tapıp] aldığımız malumat uşbudur [budur]. Türkmenler arasinda bu hakta malumat alp yazan kişi bolsa elbette edebiyat tarihımızga zor hıdmet itken bolur idi" (Şura, 1913: 13/393) diye bu bölümü toparlamaktadır.

\section{Mahtumkulu'nun şiirleri hakkında ve şaire ait şiirlerin tespiti}

Zeki Velidi Togan, Mahtumkulu'nun şiirleri hakkındaki görüşlerini A. Vambery'nin ve Samoyloviç’in verdiği bilgilerle dile getirmektedir. Kendi görüşünü ise "Mahtumkulu'nun mecmua-1 eş'ari [şiirlerin toplumu]" adlı Şura dergisinin Mahtumkulu ile yazı dizisinin IV. bölümünde anlatır.

Düşünür, konuya Abdurrahman Niyazi Efendi'nin divanından başka birkaç şiir mecmuaları bilinmekte olduğundan söz açmaktadır. Ancak düşünür, Mahtumkulu'nun yazma divanının kendinde bulunduğunu belirtmektedir. $\mathrm{Bu}$ yazmanın ise kâmil divanların birisi olduğunu Şura dergisinin “Mahtumkulu'nun mecmua-i eş'ari” adlı bölümde "Buların arasında in geniş kâmil benim öz kolumdaki yazma nüshadır" diye ifade etmektedir (Şura, 1913: 13/394). Bu yazma nüshanı düşünüre "Hokantta yerli muallim Aşur Ali Efendi Zahirov" tarafından verildiğini söylemektedir (Şura, 1913: 13/394). Düşünürün Hatıralar adlı eserinde bu konuda "Khokandlı Aşur Ali Zahiri” ile mektuplaştığını görebiliriz (Togan, Hatıralar, s. 399). Ayrıca düşünür kendisinde olan yazmanın müsteşriklerin gören diğer tüm nüshalarından geniş olduğunu belirtmektedir.

Zeki Velidi Togan bu bağlamda Abdurrahman Efendi'nin 45 kaside, Vambery'nin 31 tam kaside 10 kadar kıt'alar ile cemi 41 kaside neşir ettiğini zikir etmektedir. Bununla beraber Berezin Турецкая Хрестоматия adlı eserinin şaire ait beyit kaside olduğunu belirtmektedir. Ayrıca Şeyh Süleyman'ın Lügati Çağatay ve Türkî Osmanî adlı eserinde sözlüklere örnekleme bakımından 18 yerde $^{10}$, Mahtumkulu'nun şiirlerinden getirdiğini belirtmekte ve tek tek sayfalarını göstermektedir (Şura, 1913: 13/394). Bununla birlikte şairin şiirlerinin meşhur

\footnotetext{
${ }^{9}$ См. Зап. Вост. Отд. Имп. Русс. Арх. Общ. Т. XVIII. Смр. 0159, сп. 4, и протоколы засъданий того общ. т, стр. XIX, и т, XIX, стр. 08.

${ }^{10}$ Şairin şiirlerinin olduğunu sayfalar: 3, 13, 15, 20, 34, 39, 63, 108, 158, 168, 198, 204, 211, 259, (259), 278, 294, 295. Şeyh Süleyman Efendi, Lügati Çağatay ve Türkî-i Osmanî, İstanbul 1298/1882.
} 
Ostroumov tarafından neşir olunduğunu belirtmiştir (Mahtumkulu, 1907: 127). Ancak düşünürün onu göremediğini beyan etmektedir (Şura, 1913: 13/394). Son olarak ta Samoyloviç'in Mahtumkulu'nun divanının altı nüsha olduğunu ve bir kaçını başka nüshalarda gördüğünü ifade etmiştir. Sonuç olarak Samoyloviç'in gördüğü gazallerinin sayısının 197 olduğunu belirtmektedir (Şura, 1913: 13/394). Bu arada yazar dipnotta gazal kelimesinin Orta Asya halk şairlerinin şiirlerine isim olarak verildiğine dair bilgiye de dikkat çekmiştir (Şura, 1913: 13/394).

Zeki Velidi Togan Mahtumkulu'nun şiirlerinin sayısı konusunda da kesin bir düşünceye sahip olduğunu şu sözler ile beyan etmektedir: "Gerek bizin gördüğümüz, gerek Samoyloviç’in gören kasideleri barısı da bir birisi ile tedahül ederler. İşte bu sebepten hazır ki [şimdi ki] malum olan türlü mecmualardaki kasidelerin adedi nice yüzlere yetse de hakikatte barısı 270 le beden artmay [geçmez]" (Şura, 1913: 13/394). Bu konuda kendisi bir sayım yapmaktadır. Gerçekten de yazarın kendi dönemindeki şiirler hakkındaki sayımı görmeye değerdir. Bu konuda yazar "Bizim koldaki mecmuada barısı 209 gazal, munda [bunda] başkalar tarafından görülen 80 kadar kaside yok. Ama özünde başka oryantalistler tarafından görülmeyen 68 gazal bar. Samoyloviç barısı 197 gazal (buların 137-si) bizin mecmuada bar. + bizin mecmuada gene olmayan 68 + Vambery mecmuasinda gene olmayan $2+$ Abdurrahman Efendi mecmuasında gene olmayan 2 = bular barısı bula 269 gazal” diye belirlemektedir (Şura, 1913: 13/394-39).

Düşünür kendi döneminde bilinen Mahtumkulu'nun tüm şiirlerinin 269 olduğunu ifade etmiştir. Ancak yazının devamında bu sayıdan fazlasını şimdilik tespit etmenin olanaksız olduğundan söz açmaktadır. Bunun bir sebebi de Samoyloviç’in beyitleri tertipleme konusu olduğunu da ifade etmekte ile onun bir kriter ve ölçüt takip etmemesi oluğundan sayının tam belirlemesi de uygunsuzluğa sebebiyet vermekte olduğu yönünde görüş belirtmiştir (Şura, 1913: 13/395). Sonra ise yazar: “Allah tilese kileçekde bir firsat ile Mahtumguli eş’arine (şiirlerine) aid bazı bir teftişler (разборы) yazarmız (yazarıs). Bu seferge (defa) edebiyat muhiblerine (âşıklarına) bir buluşluk bolsun dib, muhterem şairlerin nin dey gazalleri bar ikenin görsetu üçün (için) "Mahtumkuli’nin gazallerine körsetkiç (gösterge)" yazdım. Hazır ki koldan körsetkiç şol (geleni şu)" (Şura, 1913: 13/395.) diye bölümü tamamlamaktadır.

\section{Mahtumkulu'nun şiirlerinin sayısı}

Yazar bu konuda "Mahtumkulu'nun eş'arine (şiirlerine) görsetiç" adlı bölümü Şura dergisinin 14. - 15. -16. - 17. sayılarında dile getirmiştir. Nitekim yazar yazının girişinde kendi elindeki yazma esasında tertiplediğini ve ayrıca da Samoyloviç’in neşrinde olanları "S", Vambery'nin neşrinde olanları "V", Abdurrahman Efendi'nin divanindekilere ise "A" işaretini verdiğini belirtmektedir. Bununla beraber onların neşirlerindeki sayı numaralarını hem ayrıca 
belirttiğini de zikir etmiştir. Şairin şiirlerinin tertibini ise, Arap harflerini esas alarak ve şiirin iki setrini getirerek, şu şekilde düzenlemiştir. Örneğin:

"Elif"

1) V. 144, S. 4. [Bu dünya]

Maşrykdan magryba dünýäniň ýüzi,

Diýmäň, bize mälim däldir bu dünýä, (Şura, 1913: 14/424.)

Zeki Velidi Togan'ın "Mahtumkulu'nun şiirlerinin gösterge" adlı bölümü, şairin şiirleri bakımından çok önemlidir. Çünkü şairin şiirlerinin aidiyeti konusunda şüphelerin kalkmasına ve kesinleşmesine olumlu katkı sağlayacağını söyleyebiliriz. Bu öneme binaen şairin şiirlerinin göstergesini, günümüz Türkmence adları ile zikretmeyi uygun gördük.

1) Bu dünýä, 2) Rebbiýel-Ala, 3) Gelen eşýa, 4) Duman peyda, 5) Ryýadan, ýa Reb, 6) Bir-birine bezebip, 7) Jem bolup, 8) Set jan, eý, dost, 9) Köýmen ýigide, 10) Ýeldim tut, 11) Köňül ýalmaz hiç, 12) Saçdy Muhammet, 13) Adamzat, 14) Jan çykar, 15) Harap eýlär, 16) Bir beýan geler, 17) Galar, Ýaranlar, 18) Anda bar, 19) Gelse gerekdir, 20) “Turgul” diýdiler, 21) Artsa gerekdir, 22) Ýat bolar, 23) Söhbet ýagşydyr, 24) ${ }^{11}$, 25) Jeňi bellidir, 26. Başy gerekdir, 27) Dag saýar, 28) Behem eder, 29) Kürs çykar, 30) Betham olur, 31) ${ }^{12}$, 32) Kön̆ül joşundadyr, 33) Andadyr, 34) Şondadyr, 35) Geçip baradyr, 36) Syr gider, 37) Parhy kimdedir, 38) Joşy ýandyrar, 39) Göze myhmandyr, 40) Şalar galmazlar, 41) Keçdir ýaranlar, 42) Donly görner, 43) Batdy ýaranlar, 44) Aly sizindir, 45) Utup durupdur, 46) Äleme belgilidir, 47) Myhmanydyr, 48) Gelen-de bardyr, 49) Eýmenewer, 50) Reftarydyr, 51) ${ }^{13}$, 52) Irnip durupdyr, 53) Risman dakarlar, 54) Bibat görüner, 55) ${ }^{14}$, 56) Şasy galandyr, 57) Ata meňzer, 58) Oýan diýdiler, 59) Çagdyr bu çaglar, 60) Çagdyr bu çaglar, 61) Bar my, ýaranlar, 62) Hakdyr, 63) Anbar saçdylar, 64) Mir olur, 65) ${ }^{15}$, 66) Gymmat ýagşydyr, 67) Geldi ýaranlar, 68) Donly görner, 69) At ýanynda bellidir, 70) Gidip baradyr, 71) Iglerler, 72) Han dörer, 73) Höwesidir, 74) Para-paradyr, 75) ${ }^{16}$ Döker bolduk ýaşymyz, 76) Ýaraşmaz, 77) ${ }^{17}$, 78) Düýşüne degmez, 79) Öňi-ardy bilinmez, 80) Pygan eglenmez, 81) Salar guşun aňlamaz, 82) Peýany bolmaz, 83) ${ }^{18}$, 84) Yhsan kaýsy bilinmez, 85) Malyna degmez, 86) Döwran tapylmaz, 87) Çykyp oturmyş, 88)

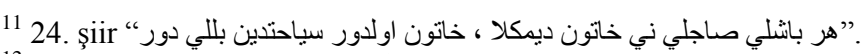

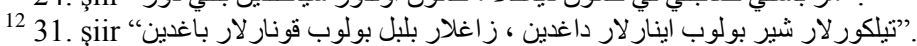

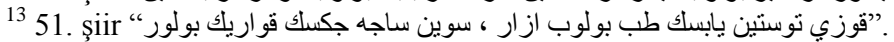

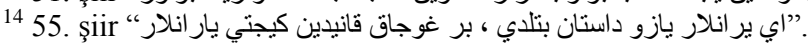

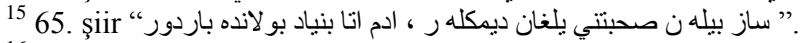

${ }^{16}$ Yazar derginin 14. sayısında 74. şiirle bitirmekte olsa da, 15. sayıda 76. şiirle başlamaktadır. Ancak 76. şiiri diziye uygunluk olsun diye 75. şiir olarak devam ettik.

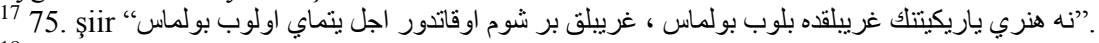

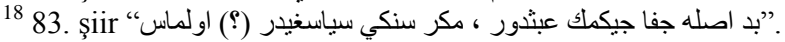


Gitmezmiş, 89) Nas atan, 90) Gybatkeş, 91) Munda, çilimkeş, 92) Ýaşyl zümerret, 93) Aty gerek, 94) Baş bolman, 95) Otur-turşun görün, 96) Atamyň, 97) Bilmezmiň, 98) Joşa ýetdiň, 99) Özi behiştiň, 100) Byragyň, 101) Döwlet Alynyň, 102) ${ }^{19}$, 103) Halyma meniň, 104) Gul bolgul, 105) Gürz dälmi?, 106) Görgöç, Resul, 107) Ýa Resul, 108) Köňül, 109) Ýetişti salym, 110) Guluň boldum, 111) Hijran haýsy, bilmedim, 112) Galmagaly neýlerem, 113) Eýýämi gördüm, 114) Köňlüm, 115) Gyzmaly boldum, 116) Ynsan ýaratdy, 117) Ýagmyr ýagdyr, Soltanym, 118) Aşyk bolmuşam, 119) Arap tilli söwdügim, 120) Seda boldum, 121) Badysabany görsem, 122) Sataşdym, 123) Iki helalym, 124) Ädejek sen, 125) Baka-baka gider sen, 126) Bolar sen, 127) Joş bolmasyn, 128) Biwepalardan, 129) ${ }^{20}$, 130) Haky çün, 131) Uça bilmen, neýläýin?!, 132) Aglaryn, 133) Üçi öwlatdan?, 134) ${ }^{21}$ Kararsyz ärden, 135) Özüňden!, 136) Bir görüp gitse daşymdan, 137) Çykardym çenden, 138) Binamaz çirkin, 139)22 Bola-bola gider sen, 140) Näge ýatyp sen?, 141) Ýeter sen, 142) Göçer sen, 143) Alydyr, 144) Abat galsyn, 145) Dag-u hasratdan nyşan, 146) Ölmesden burun, 147) Galyp men, 148) Içer bir gün, 149) Gördüňmi?, 150) Gelmezmi?, 151) Daşlar bile, 152) Gitti bu raýa, 153) Baş üstüne, 154) Diş gitmek, 155) Köz bile, 156) Ar bile, 157) Duz hem bolmasa, 158) Girýandadyr-girýanda, 159) Aman heý, 160) Kär bile, 161) Gidiji bolma, 162) Duşsaň derdi-belaga, 163) Galandar bile, 164) Döndi döwür ýamana, 165) Ýel bile, 166) ýa, Züljelalym, 167) Don bolsa, 168) Bir sagat bile, 169) Zyýan gorse, 170) Ýusup diýe-diýe, 171) Aý-Günüňiz batmaga, 172) Boldum girýana, 173) Joş gelse, 174) Şal tapsa, 175) Meýdan ýoluksa, 176) Jan içinde, 177) Galmaz-a, 178) Gahry gana, 179) Ýolda seni?, 180) Joşan günler, heý, 181) Ýagydyr-ýagy, 182) Gökce kepderi, 183) Gözüm düşdi, 184) Söýmüşem seni, 185) Bu işi, 186) Söýmüşem Seni, 187) Ykbal bolmady, 188) Ýar bizim sary, 189) Päliň seniň, 19023 ${ }^{23}$ 191) Bilbil nalasy, 192) Diwana geldi, 193) Keffaret etdi?, 194) Lewada belli, 195) Ýerbe-ýer geçdi, 196) Nogsana gelgeý, 197) Saly, dünýä, heý, 198) Ynsan ýaratdy, 199) Gaça başlady, 200) Rowan oldy, 201) Aýyň ýagşysyn, 202) ${ }^{24}$ Harap eýlär, 203) Ussada, belli, 204) Bagyşla bizni, 205) Edip geçdi, 206) Näler boldy?!, 207) Hezar astana sary, 208) Tasa garşy, 209) Delalat ýagşy, 210) Galmaz-a, 211) Ýel bile, 212) Ýeldim tut, 213) Sözüm bar, 214) Jan çykar, 215) Ýar çeker, 216) Repbim Jelil, 217) Gökden inmez, ýaranlar, 218) Emire döner, 219) Jahan Senden bihabar, 220) ${ }^{25}, 221$ ) Döküp baradyr, 222) Gumly çykypdyr, 223) Alnymyza gelse gerekdir, 224) Barsa gerekdir, 225) Başy gerekdir, 226) Anda bar, 227) Pelegidir, 228) Är ýanynda bellidir, 229) Içen ýalydyr,

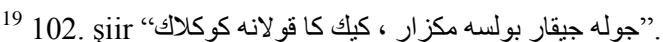

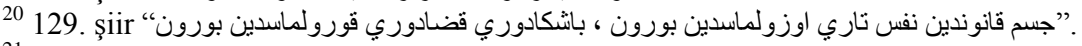

${ }^{21}$ Yazar derginin 15. sayıda 132. ve 133. şiirle bitirmekte olsa da, 16. sayı1da da 132. ve 133. şiirlerle başlamaktadır. Ancak şiiri diziye uygunluk olsun diye önceki doğrultuda devam ettik.

${ }_{22}^{2}$ Yazar derginin 16. sayıda 138. sayı yok. Ancak şiiri diziye uygunluk olsun diye önceki doğrultuda devam ettik.

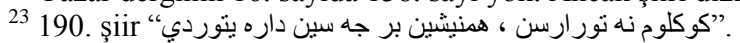

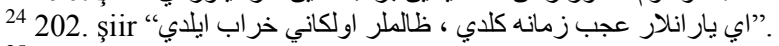

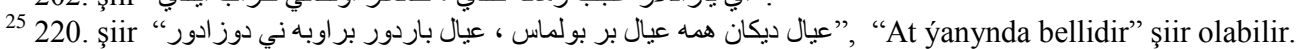


230) Daşy syndyrar, 231) Emri-Han geler, 232) Näler görüner, 233) ${ }^{26}$ Gadryn näbilsin, 234) Don gerek, 235) Ýüz ursaň, 236) Päli bendäniň, 237) Öýlengin, 238) Jahan gördüm, 239) Mährap kaýsy, bilmedim, 140) ýa, Züljelalym, 141) Ýoldaş bolan, 242) Joşa düşüp sen, 243) Näme Sen?, 244) Näbilsin, 245) Ýykmaýan ärden, 246) Sözi geçer janyňdan, 247) Ýüregiň gan içinde, 248) Many bilmez ýaşynda, 249) Ne iş geler başymyza, 250) Ýarym, ýa, Alla, 251) Ýyglap geçer halymga, 252) Gaşy ýaý, 253) Çaldy gitdi, 254) Bu derdi, 255) Bir nan getirdi, 256) Bir işe ulaşdy, 257) Ýat ýagşy, 258) Gürz dälmi?, 259) Sözlemeýin bolarmy?, 260) Iki dünýäniň soltany, 261) Dini biläni, 262) Baglar, heý, 263) Joşan günler, heý, 264) Aman heý, 265) Sazyna degmez, 266) Sil galmaz, 267) Abat galsyn, 268) At islärin, 269) Enede bizni.

\section{Mahtumkulu'yu anlamak}

İlk üç bölümü yazarın Şura adlı dergi de yayınladığı "Mahtumkulu Divani” adlı yazı dizisinin esasında değerlendirmeye gittik. Ancak bu bölümde Zeki Veli Togan'ın Türkiyat Mecmuası'nın “Kitabiyat tenkid ve tahlilleri” bölümündeki Şeyh Muhsin Fani tarafından şerh ve tenkitli Mahtumkulu divanı ve yedi asırlık Türkçe bir manzume adlı kitaba yazan geniş analizlerinin esasında çözümlemeye ve anlamaya çalışılacaktır ${ }^{27}$.

Köprülüzade Fuat Beğ'in Illk mutasavvıflar adlı eserinde "Mahtumkulu'ya bir saz şairi olmakla beraber hemem hemem Ahmet Yesevi tesirinde olan bir derviş olarak tavsif ediyor" (Köprülü, 1976: 177) diyerek ilkesini belirleyen Zeki Velidi Togan, bu konuyu tekrar ele alma sebebini şu sözler ile ifade etmektedir: “Türkiye'de ilmi maksatla Türkiyat'a ait yazllan beraber ele alındığl vakit, ilk evvel göze çarpan cihet, hiç olmazsa Türk kavimleri lisanında neşir olunan Asarı cami' bir kütüphanenin bulunmaması, ve diğer taraftan da, diğer Şark ülkelerindeki gibi Türkiye'de çalışan âlimlerinde yalnız münferit olarak çalışmaları, ve ulumun müteaddid şuabatı şöyle dursun hatta bir fen yolunda çalışanlar arasında bile teşriki mesai usulünün mevcut olmamast ve ona sevk eden müessesatı ilmiyenin ademi mevcudiyetidir. Yoksa bir eser üzerinde bu kadar emek sarf etmekten çekinmeyen müsteidd ve muktedir zevat mevcut iken, bu klymetli vakitlerin ve bu emeklerin beyhude yere bir takim tedahüllere, tekrarlara sarf olunarak heder olup gitmesinden ictinap etmek elbette mümkün olurdu. İste, yalnız bu hakikati acı misallerinden biriyle göstermek için, "Şeyh Muhsin Fanî"nin bu küçük eserini bu kadar tafsilatiyla tahlil ettim" (Togan, 2013: 202).

\footnotetext{
26 233. şiir “دكرمنجي قولينه جوشه الغز باز ، قانتندين اير قدرين هيج بلمز".

${ }^{27}$ Mahtumkulu'nun şiirlerini, Şeyh Muhsin Fani tarafından şerh ve tenkit ederek Mahtumkulu divanı ve yedi asırlık Türkçe bir manzume adıyla neşir edilen eserini irdeleyen Zeki Velidi Togan'ın makalesi Türkiyat Mecmuası'nın "Kitabiyat Tenkit ve Tahlilleri" kısmında 465-474 sayfaları arasında yer almaktadır. (Türkiyat Mecmuası, c. II, İstanbul 1926. s. 465-474.); Zeki Velidi Togan (Çev.: Dr. Tahir Aşirov). Mahtumkulu Divanı ve Yedi Asırlık Türkçe Bir Manzume, Şerh ve Tenkit Eden: Şeyh Muhsin Fânî, İstanbul 1340." Uludağ Üniversitesi İlahiyat Fakültesi Dergisi Cilt: 22, Sayı: 2, 2013. s. 189-202.
} 
Yazar Şeyh Muhsin Fani tarafından şerh ve tenkitli Mahtumkulu divanı ve yedi asırlık Türkçe bir manzume adlı işine analiz etmeye başlamadan önce Mahtumkulu ve onun şiirleri hakkında olan kaynakları getirmekte ve şairin şiirlerinin sayı hakkında da düşüncelerini beyan etmektedir. Burada yazarın şair hakkındaki bilgilerinin yenilenme sonucunda ilerlemenin olduğunu da görülebilir. Nitekim düşünür Şura dergisinde şairin şiirlerinin Ostroumov tarafından neşir olunduğunu belirtirken, bu yazısında "Mahtumkulu” nun diğer kısımları daha 1907 senesi “Taşkent"te, "Ostroumov" tarafindan "Türkistan vilayetinin gazyeti"28 gazetesinde tefrika [parça parça] suretinde ${ }^{29}$, sonra 128 sahifelik [sayfallk] bir risale suretinde 50 dane olarak neşir olunmuştur" diyerek şöyle devam etmektedir (Mahtumkulu, 1907: 127): "Mezkûr divanın "Ostroumov" tarafından neşir olunan kısmı Türkiyat enstitüsü kütüphanesinde numara 3752 deki ufak risaleler içinde mevcuttur: Lakin maalesef Katanov kütüphanesi ${ }^{30}$ vaktiyle iyi tanzim olunmamış [düzenlenmemiş] ve bilhassa küçük risaleler kendi isimleriyle yazılmamış olduğundan, o cümleden, Mahtumkulu divani'de kendi ismiyle kayıt olunmamıştır". Bugün Türkiyat enstitüsü kütüphanesinde 3752 numaralı risalenin kayıt yerinde olmadığından kayıttan düşürülmüş olduğunu ve ata mirasımıza ait belgelere ne kadar sahip çıktığımızı kütüphaneye ziyaret eden her bir araştırmacı öğrenebilir.

Düşünür, Şeyh Muhsin Fani'nin Türk kültürü konusundaki saf ihlâsını ve ferdi gayretini takdir ettikten sonra onun neşir eden Mahtumkulu divani' ni çok temel esaslarda eleştirmektedir. Bunun yanı sıra Vambery'nin neşrine de o kadar eleştiri yöneltmektedir. Gerçekten de Türkmen kültürü abidelerinden ve büyüklerinden biri olan Mahtumkulu'yu Vambery'nin neşir ettiği sınırlı bir divanla değerlendirmek olanaksız olduğunu söylemektedir. İlk olarak Vambery şairin şiirlerine doğru okuyamadığından dolayı Şeyh Muhsin Fani’nin de doğru anlamaması kabul edilebilir bir gerçeklik olarak ifade edilmiştir. Düşünür iki yazarında hatalarından bir kaçını örnekleyerek değerlendirmeye yapmıştır. Yazar bu konuyu sonuç olarak şöyle değerlendirmekdir: "Mahtumkulu”, Türkmenin diniyatını, hükmiyatını, maziye ve istikbale nazarlarını ve umumen hayat felsefesini öğrenmek için mühim me'hazdır; ve bu halk şairi ve onun namı etrafinda temerküz eden Türkmen halk felsefiyatı hakkında, "Vambery"nin neşir ettiği 31 manzumeye bakarak hüküm çıkarmak doğru olmaz” (Togan, 2013: 201).

Zeki Velidi Togan, şair ve filozof Mahtumkulu'yu iki yönden inceleyebileceğimizi söylüyor. Bu konuda şöyle diyor: "Hive Türkmenlerinde hatta Özbeklerinde de "Mahtumkulu

\footnotetext{
${ }^{28}$ Çar hükümeti neşriyat organı olan “Türkistan Vilayetinin Geziti” 1871'de yayımlanmaya başladı. Bu gazetenin başyazarlığını 1883'e kadar Şahimerdan İbrahimov (Türkistan valisinin özel tercümanı), 1883-1917 yılları arasında ise misyoner Ostroumov yapmıştır. Müsteşrik, tarihçi ve etnograf Nikolay Petroviç Ostroumov/Николай Петрович Остроумов (1846-1930) (15 Kasim 1846 - 17 Kasim 1930)

29 Türkistan Velayatının gazeti 1907 - № 15, 16, 23, 24, 26, 28, 29, 31, 32, 34, 37, 38, 40, 41, 42, 45, 46, 47.

301914 yılında Osmanlı Sadrazamı Hilmi Paşa tarafından satın alınan bilinen ve halen T.C. İstanbul Üniversitesi Türkiyat Araştırmaları Enstitüsü Kütüphanesinin Nikolay A. Katanov bölümü olarak hizmet vermektedir.
} 
okumak", "Türkmence hikmetli mev'ize şiirleri okumak" manasinda kullanillyor. Bundan dolayl "Mahtumkulu”na nispet edilen manzumeler ikiye taksim edilerek ögrenilmelidir. Biri, "Göklen” kabilesinden olan "Mahtumkulu ibn Devlet Munla"nın bizzat kendisinin inşa ettiği eş'arını tayin etmektir. İhtimal bu zatın kendi asrında yazılan divanı da bulunabilir. "Şah Nimetullah Veli", Ahmed Yesevi" gibi halk evliyasina nispet edilen eş'ar ve asar meyaninden fil-vaki o zatların kendi eserleri olanlarını ayırıp bilmek ne kadar müşil ise, "Mahtumkulu" eserlerini bu yolda tefrik ve tetkik de, yeni bir şair olmasına rağmen, epeyce müşkildir. Maa ma fih bu mesele ayrı bir meşgale teşkil edebilir. Meselenin diğer şıkkı ise, halk ağzında "Mahtumkulu"ya nispet edilen parçaları tayindir. Bu vakit "Mahtumkulu” ismi bir ism-i cins oluyor. Şimdiye kadar bulunan 279 manzumenin ve daha bulunacakların pek çoğu belki bu cümledendir. Halk ăgzında, İslam ruhunda "Mahtumkulu” ezin ve tarzındaki hikmetli şiirlerin ekserisi ona nispet verilebilir. Birinci "Mahtumkulu"yu "yani Mahtumkulu ibn Devlet Munla"yl, biz maalesef pek az biliyoruz; ikinci nevi "Mahtumkulu" ise Türkmen halkına siyasiyat, hükmiyat, nesaih öğretiyor; Hindistan'la Türkistan'ı mukayese ediyor; aile hayatından, aşiret hayatından bahis ediyor. "Abadı harabı düzi deryası, Yüz kırk altı mün ağaç (fersah) bulur bu dünya"32 diyerek coğrafiye ögretiyor"(Togan, 2013: 200.).

Yazarın Mahtumkulu'yu nitelendirmesi çok dikkat çekicidir. Belki de ilk olarak haklı ve doğru bir betimlemenin ona ait olduğu söylenebilir. Nitekim düşünür şair hakkında ciddi bir inceleme yapmıştır. Ayrıca döneminin doğru okunması, şiirlerinin her bir kelimesinin doğru bilinmesi açısından Togan'ın tespitleri yerli yerindedir. Bunu kendi cümleleriyle şöyle gösterebiliriz: "Fergane'de bulunan divanlarda olduğu gibi, Şimali Kafkasiya'daki "İstavropol" Türkmenlerinde de mevcuttur. Bu nevi Mahtumkulu eş'arı dini olmakla beraber "Meşrep" veya "Ahmed Yesevi" gibi halis tasavvuf eseri ve derviş eş'arı değildir. Bu bir halk din ve ahlak muallimi, halk felsefiyati muallimidir" (Togan, 2013: 200).

\section{Sonuç}

Edebiyat, toplumun düşünce yapısının, fikriyatının, kültürünün aynalarından biridir. Türk medeniyetinin mensubu olan Türkmen şairi Mahtumkulu, şiirlerinde yaşadığ çevrenin dinî hayatına, toplumsal yaşayışına, o dönem insanlarına, halk şiirinin estetik kuralları içinde 1şık tutmuştur. Bu bakımdan Mahtumkulu'nun şiirlerinin bilinmesi Türkmen düşünce yapısı bakımından önemlidir. Bu bağlamda akademik kariyeri ve bilimsel çalışmaları ile meşhur olan Zeki Velidi Togan'ın şair Mahtumkulu ile ilgili yazıları büyük ilmî değere sahiptir. Zira bunlar onun, Mahtumkulu ve şiirleri üzerine yaptığı ince araştırmalarının ve uzun uğraşlarının bir

\footnotetext{
${ }^{31}$ Şah Nimetullah Veli, XIV-XV yüzyılında yaşamış olan tasavvuf eğilimli düşünürdür.

32 "Bu Dünya" adlı şiiri şöyledir: "Abady-haraby, derýasy-düzi, Ýüz kyrk alty müň agaç ýoldur bu dünýä." Magtymguly, Şygyrlar (üç tomluk) I tom Aşgabat “Türkmenistan” DNÇB, 1992.
} 
ürünüdür. Togan yazılarında iki notayı açıklığa kavuşturmuştur. Onlardan birincisi

Mahtumkulu'nun Yesevi meşrebine mensup bir şair olduğu ve şiirlerinin de bu geleneğe yansıttığıdır. İkincisi ise şairin, günümüzde de tartışma konusu olan, şiirlerinin sayıdır. Dolaysıyla Mahtumkulu'na dair ilk elden üretilen metinler üzerinde çalışmaların yapılması, bilinmesi, Türkmen edebiyatını, kültürünü anlama ve tanıma adına daha nitelikli, daha sağlıklı sonuçların elde edilmesini olanaklı kılacaktır.

\section{Kaynaklar}

AGABEKOV, S. (1904). Uçebnik Tyurkmenskogo Nareçiya s Prilojeniyem Sbornika Poslovits $i$ Pogovorok Tyurkmen Zakaspiyskoy Oblasti. Aşkabat.

AŞYROW, Tahyr. (2014). Magtymgulynyn̆ Türkiýedäki Ilkinji Neşri. Türkmen dili. № 7 (729).

BAKULIN, F. (1872). Pesni turkmen i poet ih Mahdum-Kuli. İzvestiya Kavkazskogo otdela russkogo geografiçeskogo obşçestva. t. I. Tiflis.

DIVAN MAHTUMKULU. (1912). Astrahan: Omarov ortaklartn tecarethana tip. (yay. Abdurrahman Niyazi).

KÖPRÜLÜ, M. Fuat. (1976). Türk Edebiyatı'nda Ilk Mutasavvıflar. Ankara: Diyanet işleri başkanlığı yayınları. (3. Baskı). (Yay. Orhan F. Köprülü)

MAGTYMGULY. (1992). Şygyrlar (üç tomluk). I. tom Aşgabat: Türkmenistan DNÇB.

MAHTUMKULU. (1907). Şiirleri. Taşkent: (haz. N. P. Ostroumov).

ŞEYH SÜLEYMAN EFENDİ. (1298/1882). Lügati Çağatay ve Türkî-i Osmanî. İstanbul.

TOGAN, Z. V. (1913). Divanı Mahtumklu. Şura. 12, 357-360. 13, 393-395. 14, 424-428. 15, 458-460. 16, 491-494. 17, 522-524. Orenburg.

TOGAN, Z. V. (1999). Hatıralar (Türkistan ve Diğer Müslüman Doğu Türklerinin Milli Varlık ve Kültür Mücadeleleri), Ankara: TDV yay.

TOGAN, Z. V. (2013). Mahtumkulu Divanı ve Yedi Asırlık Türkçe Bir Manzume, Șerh ve Tenkit Eden: Şeyh Muhsin Fânî, İstanbul 1340. Uludağ Üniversitesi İlahiyat Fakültesi Dergisi Cilt: 22, 189-202. (çev.: Dr. Tahir AŞİROV).

VAMBERİ, A. (2003). Puteşestviye po Sredney Azii. Moskova: Vostoçnaya literatura.

VAMBERY, H., Die Sprache der Turkomanen und der Diwan Machdumkuli's. ZDMG (Zeitschrift der Deutschen Morgenländischen Gesellschaft), XXXIII, s. 387-444.

Zap. Vost. Otd. İmp. Russ. Arh. Obşş. T. XVIII. Smr. 0159, sp. 4, i protokolı zasdaniy togo obşç. t, str. XIX, i t, XIX, str. 08.

Zapisok Vostoçnogo Otd. İmp. Russ. Arheolog Obşşestva. Za. (1909). t. XIX, 151. 